\title{
ENGINEERING SOIL PROPERTIES OF BHAKTAPUR POTTERY
}

\author{
Ratna Shova Prajapati, Rameshwor Shrestha
}

Civil Engineering Department, Khwopa College of Engineering, Libali-8, Bhaktapur, Nepal

\begin{abstract}
Pottery is one of the historic occupations of people of Bhaktapur. The tradition has been handed over to many successors, and the culture is still alive. Pottery in Bhaktapur municipality is concentrated in two parts namely; Suryamadi and Pottery-Square. The pottery work is adopted by ethnic group Prajapati, only they produce ceramic products in Bhaktapur municipality. Potters collect soil from specific location of Bhaktapur; Kamalbinayak, Nangakhel, Sipadol, and Tathali, which is suitable soil for ceramic manufacture. The soil samples from pottery site Suryamadi and Pottery-Square were collected. Grain size analysis, liquid limit and plasticity limit were tested. From the analysis, the soil sample from Pottery-Square was found to be finer than that from Suryamadi. Clay content and moisture holding capacity of the Suryamadi pottery work are greater than that of Pottery-Square pottery work. It shows that the Suryamadi pottery work had high tendency to get cracks and crumbled.
\end{abstract}

Keywords: Soil, Pottery, Suryamadi, Pottery-Square, Bhaktapur.

\section{Introduction}

Pottery is an art of formation of ceramic object of required shape by heating in high temperature. Pottery is one of the human invention which started before the Neolithic period. Pottery vessels were discovered in Jiangixi, China, which were older than 18,000 BC. And early Neolithic pottery was discovered in Jomon, Japan which was about 10,500BC (Diamond, 1998). The pottery of Nepal also has a long history. Among the three main cities of Kathmandu valley, capital of Nepal, Bhaktapur is famous for heritage, culture, handicraft, curd and pottery. Pottery works were found in two places of Bhaktapur municipality; Suryamadi Pottery Square, Suryamadi and Pottery Square, Talako. Ceramics of Bhaktapur had fine quality. Mostly people use a black type clay to make pottery. From the local interviews it is found that they call it as "Dyo Cha" literally "God of Clay". Prajapati, potters of Bhaktapur, are allowed to dig clay once a year in some specific places.

*Corresponding author: Ratna Shova Prajapati Department of Civil Engineering, Khwopa College of Engineering, Libali-8, Bhaktapur, Nepal

Email: prajapati.shova@khwopa.edu.np

(Received: 2016 Sept 09 Accepted: 2016 Dec 20)
They risk life to dig the clay because fine clay is found at about 10-12 feets below the ground surface. They believe this is the only best clay for pottery. So it is curious to find the nature and composition of the clay.

\section{Case Study}

Soil samples from Suryamadi and Pottery Square were collected for the comparative study. Potters of Suryamadi collect soil from Kamalbinayak and Nangakhel, Bhaktapur, whereas the potters of Pottery-Square collect soil from Sipadol and Tathali, Bhaktapur. Nangakhel and Sipadol are the parent sources of the soil samples for Suryamadi and Pottery-Square ceramics respectively which were used in research. The soil samples were collected from the pottery site. The soil was tamped and mixed adding small amount of silt according to the potters. These two soil types provide the properties of soil which is used in the pottery of Bhaktapur municipality.

These two types of soils pass through the different lab tests. Since the soil contains fine particles. Sieve 
analysis by hydrometer were done for the grain size distribution of soil particles. Plasticity limit analysis and liquid limit analysis were also done to support the classification of the soil. The soils were classified using the standard ASTM version of Unified Soil Classification System (USCS).

\section{Result and Analysis}

The soil particle sizes were categorized according to the ASTM D2488. The grain size distribution of the soil is plotted in semi log graph. Fig 1 shows the distribution curve of both soil samples. The grain size distribution curves are almost parallel to each other on a semi log graph. So it can be said these two samples of soils are of similar grade. As per IS: 1498-1970 soil particles finer than 2 micron is designated as clay-size particles and the particle between 75 microns and 2 microns as silt size particles. From Fig 1 clay and silt particles are almost equally distributed in both soil samples.

The distribution curve of Suryamadi pottery soil is not smoother than Pottery-Square soil. The hunches show the lack in well grading of soil particle distribution. While the gradation curve of PotterSquare soil is smooth. There were no hunches in the curve also.

The soil of Pottery-Square contains large quantity of fine particles, on the other hand Suryamadi pottery soil contains slightly less amount of fine soil. The difference in percentage finer of smallest to largest particles are $41 \%$ and $51 \%$ of Suryamadi pottery and

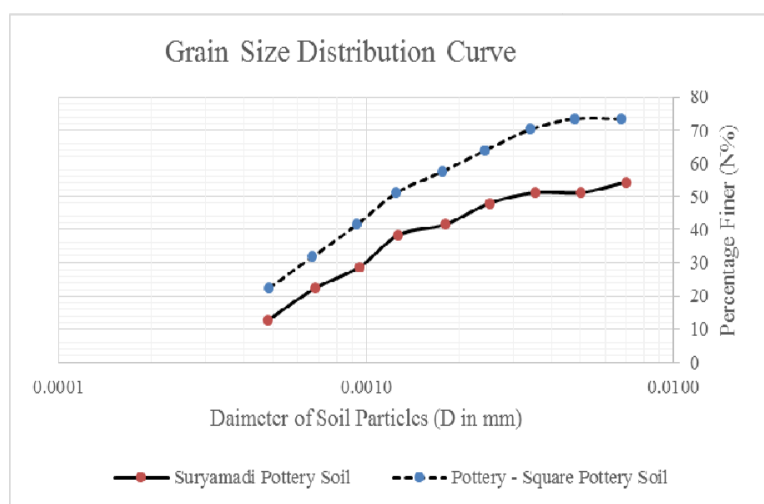

Fig 1 Suryamadi and Pottery-Square Gradation Curve.
Pottery-Square pottery respectively. This shows the Pottery-Square pottery soil contains wide range of soil particles.

Liquid limit and plastic limit are another important index properties of soil. It gives the plasticity index. As per IS: 1498-1970, the liquid limit of soil less than $35 \%$ is a soil of silt and clay of low compressibility. The low compressibility indicates volume change, shrinkage during dry period and swelling during set periods, as well as consolidation under loading. From Fig 2, the liquid limit of Suryamadi and Pottery-Square soil are $11 \%$ and $7 \%$ respectively. The liquid limits of both pottery soil is less than $35 \%$. So both soil is silt and clay of low compressibility type. The liquid limits of Suryamadi soil are higher than Pottery-Square. It also indicates that the Suryamadi pottery soil has high permeability and compressibility. The increase in these components decreases the toughness and dry strength. As per IS: 2720(5)-1985, the plasticity test gives information concerning the cohesion properties of soil and amount of capillary water which it can hold. The plastic limits of Suryamadi and Pottery-Square soil are 6\% and 3\% respectively. The plasticity index of Suryamadi and PotterySquare soil are calculated by differentiating liquid limit and plastic limit and found to be $5 \%$ and $4 \%$ respectively. Plasticity index depends on the amount of clay present in the soil (Beshy Kuriakose, 2014). From Table 1 of ASTM 2487, in sieve analysis 50\% or more pass the No. 200 sieve. The liquid limit is also less than 50 . So the soil types are categorized as inorganic silt and clays.

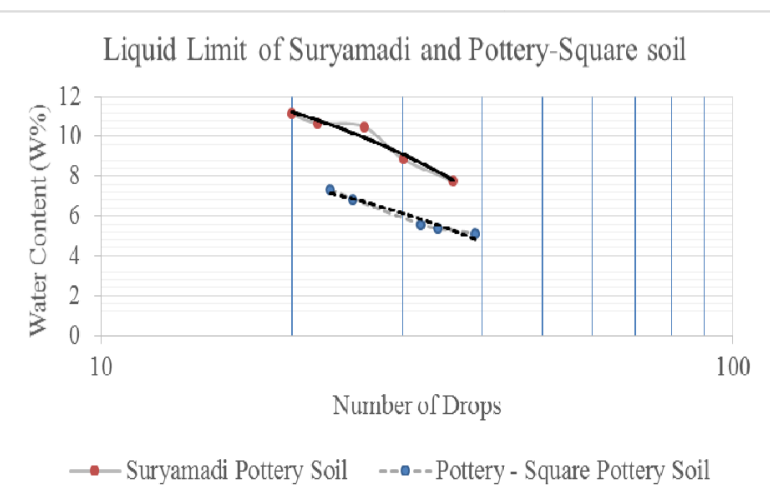

Fig 2 Liquid limit of Suryamadi and Pottery-Square soil. 
From Fig 1 and Fig 4 of ASTM 2487 with liquid limit less than 50, inorganic soil and plasticity index lies greater than and equal to 4 and less than equal to 7 and plots on or above "A" line along with soli pass greater than equal to $30 \%$ from No. 200 sieve it is categorized as silty clay with sand.

\section{Discussion and Conclusion}

Sieve analysis of soils from Suryamadi and PotterySquare was done by hydrometer method. The grain size distribution curve was plotted, liquid limit and plastic limit were also calculated. The grain size distribution of Pottery-Square soil was found to be of wide range than Suryamadi pottery soil. The increase in liquid limit and plasticity index increases the possibility of shrinkage and soiling of the Suryamadi pottery soil. The increase in plasticity index of Suryamadi pottery soil indicates that they can crack easily during burning of the pottery products. In both cases, it is found that the soil is inorganic silty clay type. Since there are no presences of organic particles, this informs the quality of the pottery work will remain undamaged. The earlier works (Jayasekera, Some Relationships Between Shrink-Swell Index, Liquid Limit, Plasticity Index, Activity and Free Swell Index, 2003) and (F. Amponsah-Dacosta, Characterization of Clays for Making Ceramic Pots and Water Filters at Mukondeni Village, limpopo Province, South Africa, 2013)also indicates same results. The clay shall be modified by adding silty soil to reduce moisture content and enhance strength.

\section{Acknowledgement}

We would like to acknowledge Khwopa College of Engineering for providing ground to explore this research work. The completion of this undertaking could not have been possible without the participation and assistance of students' of Khwopa College of Engineering 070 Batch and some active participants; Suraj Shah, Shiva Lakhan Yadav,
Sushan Duwal, Bimal Chhushyabaga, Binod Acharya, Khem Raj Pokharel.

\section{References}

[1] ASTM:2487. (2009). Standard Particle for Classification of Soil for Engineering Purpose.

[2] ASTM:2488. (2009). Standard Particle for Description and Identification of Soils.

[3] Beshy Kuriakose, B. M. (2014). A Critical Review of Liquid Limit - Plasticity Index. International Journal of Emerging Technology and Advanced Engineering .

[4] Diamond, J. (Jun 1998). Japanese Roots. Discover. Discover Media LLC

[5] F. Amponsah-Dacosta, C. M. (2013). Characterization of Clays for Making Ceramic Pots and Water Filters at Mukondeni Village, limpopo Province, South Africa. ARPN Journal of Engineering and Applied Sciences .

[6] Hechanova, R. (1982). Observation on Engineering Design, Layout and Construction of Coastal Fishpond in the Southeast Asisan Region.

[7] IS:1498-1970. (1970). Classification and Identification of Soils for General Engineering Purpose.

[8] IS:2720-1985. (1985). Methods of Test for Soils, Part 4: Grain Size Analysis.

[9] IS:2720-1985. (1985). Methods of test for soils, Part 5: Determination of Liquid and Plastic Limit.

[10] Jayasekera, S. \&. (2003). Some Relationships Between Shrink-Swell Index, Liquid Limit, Plasticity Index, Activity and Free Swell Index. Australian Geomechanics

[11] Sas, W. e. (2013). Determination of Poisson's Ratio by Means of Resonant Column Tests. Electronic Jornal of Polish Agricultural Universities . 